\title{
Model analysis of the effects of atmospheric drivers on storage water use in Scots pine
}

\author{
H. Verbeeck ${ }^{1}$, K. Steppe ${ }^{2}$, N. Nadezhdina ${ }^{3}$, M. Op De Beeck ${ }^{1}$, G. Deckmyn ${ }^{1}$, L. Meiresonne ${ }^{4}$, R. Lemeur ${ }^{2}$, J. Čermák ${ }^{3}$, \\ R. Ceulemans ${ }^{1}$, and I. A. Janssens ${ }^{1}$ \\ ${ }^{1}$ Research Group of Plant and Vegetation Ecology, Department of Biology, University of Antwerp, Universiteitsplein 1, 2610 \\ Antwerp, Belgium \\ ${ }^{2}$ Laboratory of Plant Ecology, Department of Applied Ecology and Environmental Biology, Ghent University, Coupure Links \\ 653, 9000 Ghent, Belgium \\ ${ }^{3}$ Institute of Forest Ecology, Mendel University of Agriculture and Forestry, Zemědělská 3, 61300 Brno, Czech Republic \\ ${ }^{4}$ Research Institute for Nature and Forest, Ministry of the Flemish Community, Gaverstraat 4, 9500 Geraardsbergen, Belgium
}

Received: 17 January 2007 - Published in Biogeosciences Discuss.: 21 February 2007

Revised: 15 June 2007 - Accepted: 27 July 2007 - Published: 14 August 2007

\begin{abstract}
Storage water use is an indirect consequence of the interplay between different meteorological drivers through their effect on water flow and water potential in trees. We studied these microclimatic drivers of storage water use in Scots pine (Pinus sylvestris L.) growing in a temperate climate. The storage water use was modeled using the ANAFORE model, integrating a dynamic water flow and storage model with a process-based transpiration model. The model was calibrated and validated with sap flow measurements for the growing season of 2000 (26 May-18 October).

Because there was no severe soil drought during the study period, we were able to study atmospheric effects. Incoming radiation and vapour pressure deficit (VPD) were the main atmospheric drivers of storage water use. The general trends of sap flow and storage water use are similar, and follow more or less the pattern of incoming radiation. Nevertheless, considerable differences in the day-to-day pattern of sap flow and storage water use were observed. VPD was determined to be one of the main drivers of these differences. During dry atmospheric conditions (high VPD) storage water use was reduced. This reduction was higher than the reduction in measured sap flow. Our results suggest that the trees did not rely more on storage water during periods of atmospheric drought, without severe soil drought. The daily minimum tree water content was lower in periods of high VPD, but the reserves were not completely depleted after the first day of high VPD, due to refilling during the night.

Nevertheless, the tree water content deficit was a third important factor influencing storage water use. When storage compartments were depleted beyond a threshold, storage water use was limited due to the low water potential in the stor-
\end{abstract}

Correspondence to: H. Verbeek

(hans.verbeeck@ua.ac.be) age compartments. The maximum relative contribution of storage water to daily transpiration was also constrained by an increasing tree water content deficit.

\section{Introduction}

The water balance of a tree depends on the transpirational loss, uptake from the soil and internal storage of water. Storage water use or refilling may induce a considerable time lag between transpiration and sap flow near the base of the stem (Goldstein et al., 1998). Stored water plays a biologically significant role in trees (Čermák et al., 2007). It is accessible to the individual tree only, unlike soil water, which may be taken up by other plants or lost through evaporation or drainage. Water released from storage in the stem serves as buffer to preclude low xylem water potentials that might otherwise be caused by peaks of transpiration. Therefore, the xylem water potential is smoothed along the flow path, which may help avoid xylem cavitation. Trees can use stored water to allow continued photosynthesis when transpiration exceeds soil water uptake (Zweifel et al., 2001). Despite the importance of water storage in regulating the water budget of trees, limited information exists on the contribution of internal water storage to their total daily water consumption (Meinzer et al., 2001).

Several authors found that the contribution of internal water to transpiration is not a constant in the water budget of trees (Loustau et al., 1996; Köstner et al., 1998; Zweifel et al., 2005; Verbeeck et al., 2007), but changes dynamically from day to day. To determine the complete water balance of a forest ecosystem and its dynamics, it is therefore important to know which factors influence the use of stored water.

Published by Copernicus Publications on behalf of the European Geosciences Union. 
Storage water use is driven by external meteorological factors on the one hand, and by internal physical factors on the other hand. This paper investigates the effect of the atmospheric microclimate on the use of stored water of Scots pine (Pinus sylvestris L.) for the growing season of 2000 (26 May-18 October). Since there was no severe soil drought during the study period, we were able to study the effect of atmospheric drought. Low soil water availability and high evaporative demand are often treated together as aspects of drought stress. However, their effects on plants may differ: the first is a measure of how much water is available in the source, while the second (high evaporative demand) reflects the sink effect of the atmosphere (Bhaskar and Ackerly, 2006). In contrast to low soil water availability, the influence of high evaporative demand or atmospheric drought on hydraulic traits is less well understood, in part due to the difficulty of isolating this factor (Ewers et al., 2005; Zweifel et al., 2005).

Several experimental studies mentioned by Čermák et al. (2007), calculate storage water use from sap flow measurements at different heights. In these studies, sap flow measurements at the top of the canopy are used as a measure for the transpiration at leaf level. Over the last couple of years, several models that take into account water storage have been developed to model the non-steady-state flow of water through a tree (e.g. Zweifel et al., 2005; Steppe et al., 2006), using transpiration as an input value.

Nevertheless, as suggested by Chuang et al. (2006), a stomatal model can easily be coupled with a model of the hydraulic system of a tree to provide independent time series of transpiration. This has been done by Lhomme et al. (2001) using an empirical Jarvis-type stomatal model and a big leaf transpiration model, and by Verbeeck et al. (2007) using the process-based ANAFORE model.

In this paper, the ANAFORE model was used to model sap flow and transpiration for various Scots pine trees in Brasschaat, Belgium. This model integrates a water flow and storage submodel in a process-based transpiration model (companion paper: Verbeeck et al., 2007). The goal of this study was to determine the atmospheric drivers of day-to-day and diurnal variation of storage water use.

\section{Materials and methods}

\subsection{Site description}

The forest under investigation is "De Inslag", a mixed patchy coniferous/deciduous forest located in Brasschaat $\left(51^{\circ} 18^{\prime} 33^{\prime \prime} \mathrm{N}, 4^{\circ} 31^{\prime} 14^{\prime \prime} \mathrm{E}\right)$, in the Belgian Campine region, about $20 \mathrm{~km}$ north-east of Antwerp. The site is part of the European Carboeurope-IP network and is a level-II observation plot (ICP-II forests) for intensive monitoring of forest ecosystems (EC-UN/ECE, 1996), managed by the Ministry of the Flemish Community (AMINAL). The landscape is a coastal plain, almost flat (slope $<0.3 \%$ ) and at a mean elevation of $16 \mathrm{~m}$. The climate is temperate maritime with a mean annual temperature of $9.8^{\circ} \mathrm{C}$ and $750 \mathrm{~mm}$ of annual precipitation (30 years average). The site is located in an area with high nitrogen deposition (30-40 $\mathrm{kg} \mathrm{ha}^{-1}$ year $^{-1}$; Neirynck et al., 2002).

This relatively small ( $150 \mathrm{ha})$ forest consists of many patches of different coniferous and deciduous species, with a variety of understorey species. This paper focuses on one particular Scots pine (Pinus sylvestris L.) stand, described in detail by Curiel Yuste et al. (2005). The even-aged Scots pine stand was planted in 1929. In 1997, tree density was 556 trees $\mathrm{ha}^{-1}$. In November 1999, a thinning was performed reducing the stem number to 377 trees $\mathrm{ha}^{-1}$. In winter 1999-2000, the mean DBH (Diameter at Breast Height) was $29.4 \mathrm{~cm}$, the mean height $21.4 \mathrm{~m}$.

The soil is loamy sand, moderately wet, with a distinct humus and iron B-horizon (Baeyens et al., 1993) and is classified as an Umbric Regosol (FAO classification, Roskams et al., 1997). Below the sandy layer, at a depth of 1 to $3 \mathrm{~m}$, lies a clay layer, making that the site has poor drainage, and groundwater depth is usually between 1.2 and $1.5 \mathrm{~m}$ (Baeyens et al., 1993). The soil is typically moist, but rarely saturated because of the high hydraulic conductivity of the upper sandy layers. More details about the physical and chemical properties of the soil can be found in Janssens et al. (1999) and Neirynck et al. (2002).

\subsection{Sap flow measurements}

The sap flow data used in this study were obtained during a measurement campaign during the growing season of 2000 . From 26 May until 18 October 2000, sap flow was measured on 14 sample trees (two groups of 7 trees). The main attributes of the sampled trees are given in Table 1. Leaf area of the sample trees was determined according to the method explained in Čermák et al. (1998), based on destructive measurements on a series of sample trees from the same stand. Sapwood area was estimated from the radial sap flow profiles: the border between sapwood and heartwood was found where sap flow reached zero.

The sap flow in the sample trees was measured with the heat field deformation (HFD) method (Nadezhdina et al., 1998, 2004, 2006; Nadezhdina and Čermák, 2000; Čermák et al., 2004). This method is based on the observed changes of an artificial heat field around a linear heater in a tree stem, which depends on the sap flow rate and the xylem tissue properties. Deformation of the heat field generated by the linear heater in a certain tangential section of the stem is characterized by the ratio of temperature gradients measured around the heater in the axial and tangential directions. This ratio represents the basis for sap flow calculation.

Two types of sensors were used for the sap flow measurements in the sample trees: small, single-point sensors for routine sap flow measurements during the entire growing 
season and long, multi-point sensors for the determination of the variable flow pattern along the xylem radius in the tree stem. Each sap flow sensor consisted of two sets of differential thermocouples and a linear heater. Needles of the multi-point sensor contained six thermocouples, 10 or $16 \mathrm{~mm}$ apart. Four multi-point sensors were used, resulting in 24 measurement points. By moving the needles along the radius at half the distance between the thermocouples ( 5 or $8 \mathrm{~mm}$ ), 24 additional measuring points were obtained (Nadezhdina et al., 2002, 2007). The conducting system of stems at breast height was therefore characterized by a total of 48 measuring points in each sample tree. The radial pattern was used to scale-up the flow from routine single-point measurements to the whole tree level, according to the procedure previously described by Nadezhdina et al. (2002). The sap flow was measured every minute and recorded as means over $15 \mathrm{~min}$ intervals by data loggers (EMS-12, Unilog \& Environmental Measuring Systems Inc., Brno, Czech Republic).

Sap flow methods deal with methodological and integration problems (Köstner et al., 1998) that introduce uncertainty on the measurements. At the tree level, the most important error introducing factors are: non-uniformity of the sap flow along the radius (when radial pattern is neglected), determination of the sapwood depth, positioning of sensors beneath the cambium, possible non-parallelism of inserted needles, differences in xylem heath conductivity and temporal variations.

\subsection{Supporting measurements}

Meteorological parameters, i.e. global radiation (pyranometer, Kipp and Zonen CM6B, the Netherlands), net radiation (REBS 07, Seattle, WA, USA), photosynthetically active radiation (PAR, JYP-1000 sensor, SDEC, Tours, France), air temperature and relative humidity (Didcot Instrument Co Ltd, Abingdon, United Kingdom DTS-5A), wind-speed (Didcot DWR-250G) and precipitation (Didcot DRG-51) were continuously measured at the top of a tower $(40 \mathrm{~m})$ located within the Scots pine stand, and recorded halfhourly on a data logger (Campbell CR10, CSI, Logan, UT, USA). More details about the instruments and methods (e.g. gapfilling) used at the site can be found in Overloop and Meiresonne (1999), Kowalski et al. (2000) and Carrara et al. (2003).

Soil moisture was measured twice a week at two locations in the vicinity of the two groups of 7 Scots pine trees with a series of TDR-sensors (Time Domain Reflectometry), placed every $25 \mathrm{~cm}$ down to a depth of $175 \mathrm{~cm}$ (cabletester: Tektonix 1502B, Redmond, USA). Volumetric soil water content measurements were linearly interpolated to obtain estimates for the entire measurement period. Soil water potential was calculated from the volumetric soil water content using the power function model of van Genuchten (1980). Parameters for the soil water retention curve were determined at the site by Meiresonne et al. (2003).
Table 1. Main attributes of the 14 sampled Scots pine trees in the year 2000 at the experimental plot in Brasschaat, Belgium. All values are reported for individual trees. Diameter at breast height $(\mathrm{DBH})$, height $(\mathrm{H})$, sapwood area (SA), leaf area (LA), leaf-tosapwood area (LA/SA).

\begin{tabular}{cccccc}
\hline $\begin{array}{c}\text { Tree } \\
\#\end{array}$ & $\begin{array}{c}\text { DBH } \\
(\mathrm{cm})\end{array}$ & $\begin{array}{c}\mathrm{H} \\
(\mathrm{m})\end{array}$ & $\begin{array}{c}\text { SA } \\
\left(\mathrm{cm}^{2}\right)\end{array}$ & $\begin{array}{c}\text { LA } \\
\left(\mathrm{m}^{2}\right)\end{array}$ & $\begin{array}{c}\text { LA/SA } \\
\left(\mathrm{m}^{2} \mathrm{~cm}^{-2}\right)\end{array}$ \\
\hline 11 & 36.0 & 18.2 & 564 & 90.5 & 0.16 \\
12 & 32.5 & 18.1 & 494 & 75.1 & 0.15 \\
13 & 31.2 & 19.0 & 511 & 69.3 & 0.14 \\
14 & 29.9 & 16.3 & 428 & 65.3 & 0.15 \\
15 & 27.9 & 15.2 & 393 & 56.7 & 0.14 \\
16 & 26.7 & 15.9 & 320 & 53.7 & 0.17 \\
17 & 30.6 & 15.5 & 430 & 66.1 & 0.15 \\
21 & 34.4 & 23.1 & 563 & 82.7 & 0.15 \\
22 & 32.2 & 22.0 & 424 & 74.3 & 0.18 \\
23 & 29.6 & 16.7 & 425 & 63.3 & 0.15 \\
24 & 28.2 & 19.2 & 423 & 58.6 & 0.14 \\
25 & 26.7 & 19.9 & 420 & 53.3 & 0.13 \\
26 & 23.7 & 16.0 & 297 & 41.9 & 0.14 \\
27 & 27.7 & 18.4 & 434 & 57.1 & 0.13 \\
\hline
\end{tabular}

\subsection{Model description}

The ANAFORE model (ANAlysis of FORest Ecosystems) is a mechanistic tree and forest stand model. To model water fluxes, it integrates a dynamic water flow model in a process based transpiration model as described in a companion paper by Verbeeck et al. (2007). Stomatal aperture, sap flow, photosynthesis (Farquhar et al., 1980) and transpiration (Penman, 1948; Monteith, 1965) are simulated on a half-hourly basis. The most relevant equations to model water fluxes are described below.

The stomatal conductance model is derived from the formula of Dewar (2002), and described in Verbeeck et al. (2007):

$g_{s}=\frac{\left[a_{1}\left(A_{n}+R_{d}\right)+b\right]}{c_{i}\left(1+\frac{\mathrm{VPD}^{2}}{D_{0}}\right)} \exp \left\{-[\mathrm{ABA}] \beta \exp \left(\delta \psi_{\text {leaf }}\right)\right\}$

where $g_{s}$ is the stomatal conductance to $\mathrm{CO}_{2}\left(\operatorname{mol~} \mathrm{CO}_{2}\right.$ $\left.\mathrm{m}^{-2} \mathrm{~s}^{-1}\right), A_{n}$ is the net leaf $\mathrm{CO}_{2}$ assimilation rate (mol $\left.\mathrm{CO}_{2} \mathrm{~m}^{-2} \mathrm{~s}^{-1}\right), R_{d}$ is the dark respiration rate $\left(\mathrm{mol} \mathrm{CO}_{2}\right.$ $\left.\mathrm{m}^{-2} \mathrm{~s}^{-1}\right), c_{i}$ is the intercellular $\mathrm{CO}_{2}$ concentration (mol $\mathrm{CO}_{2} \mathrm{~mol}^{-1}$ air), VPD is the atmospheric vapour pressure deficit $(\mathrm{kPa}), a_{1}$ (dimensionless), $b\left(\mathrm{~mol} \mathrm{CO}_{2} \mathrm{~m}^{-2} \mathrm{~s}^{-1}\right)$ and $D_{0}\left(\mathrm{kPa}^{2}\right)$ are empirical constants which are parameter combinations, $[\mathrm{ABA}]$ is the leaf xylem concentration of abscisic acid (ABA) (mol ABA m${ }^{-3}$ ), $\psi_{\text {leaf }}$ is the leaf water potential (MPa), $\beta$ is the basal sensitivity of stomata to ABA $\left(\mathrm{m}^{3} \mathrm{~mol}^{-1} \mathrm{ABA}\right)$ and $\delta\left(\mathrm{MPa}^{-1}\right)$ is a factor relating stomatal 


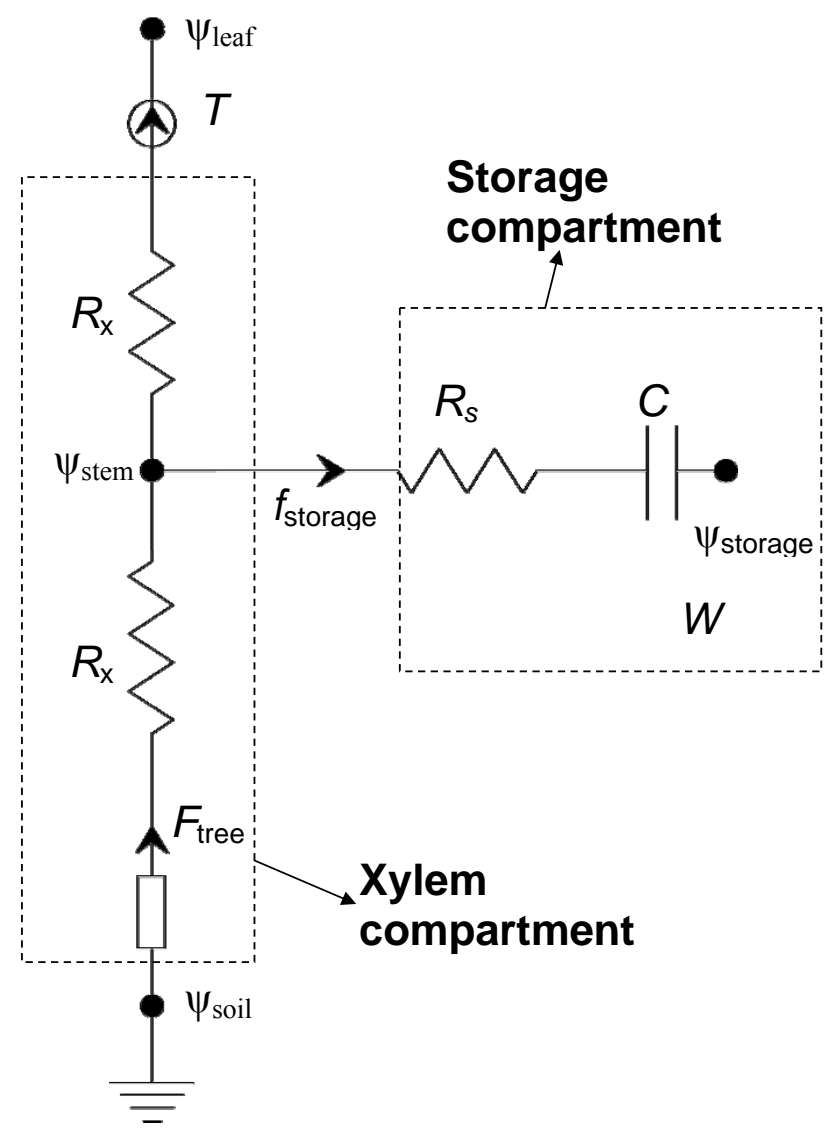

Fig. 1. Electrical analogon diagram of the water storage model. Xylem and storage compartments are shown. $\psi_{\text {soil }}$ : soil water potential, $\psi_{\text {stem: }}$ : water potential of the xylem in the stem, $\psi_{\text {leaf }}$ : leaf water potential, $\psi_{\text {storage}}$ : water potential in the storage compart-

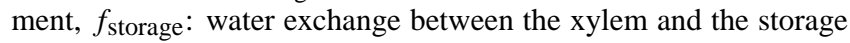
compartment, $F_{\text {tree }}$ : water flow in the stem, $R_{S}$ : exchange resistance between the xylem and the storage compartment, $R_{X}$ : flow resistance of the xylem, $C$ : capacitance of the storage compartment, $T$ : canopy transpiration rate, $W$ : water content of the storage compartment.

ABA sensitivity to $\psi_{\text {leaf. According to Dewar (2002), the }}$ leaf xylem concentration of ABA is calculated as follows:

$$
[\mathrm{ABA}]=\frac{-\lambda_{\text {root }} \psi_{\text {root }}-\lambda_{\text {leaf }} \psi_{\text {leaf }}}{V_{w}(T+a)}
$$

where $\psi_{\text {root }}$ and $\psi_{\text {leaf }}$ are the root and leaf water potentials (MPa), $\lambda_{\text {root }}$ and $\lambda_{\text {leaf }}$ are the root and leaf ABA synthesis coefficients, $V_{\mathrm{w}}$ is the molal volume of $\mathrm{H}_{2} \mathrm{O}, T$ is the canopy transpiration rate $\left(\mathrm{mol} \mathrm{H}_{2} \mathrm{O} \mathrm{m}^{-2} \mathrm{~s}^{-1}\right)$ and $a$ is the effective ABA sequestration rate $\left(\mathrm{mol} \mathrm{H}_{2} \mathrm{O} \mathrm{m}^{-2} \mathrm{~s}^{-1}\right)$. The equations of the stomatal conductance model (Eq. 1) and the photosynthesis model of Farquhar et al. (1980) are simultaneously solved according to Op de Beeck et al. (2007).

The actual transpiration of the sunlit and shaded fraction of each canopy layer is calculated according to the Penman-
Monteith approach (Penman, 1948; Monteith, 1965):

$$
\lambda E=\frac{s\left(R_{n}-G\right)+\rho_{a} c_{p} g_{b}(\mathrm{VPD})}{s+\gamma\left(\frac{g_{b}}{g_{w}}\right)}
$$

where $E$ is the leaf transpiration rate $\left(\mathrm{kg} \mathrm{m}^{-2} \mathrm{~s}^{-1}\right), \lambda$ the latent heat of vaporization $\left(\mathrm{J} \mathrm{kg}^{-1}\right), s$ the slope of the saturated water vapour pressure curve $\left(\mathrm{Pa}^{\circ} \mathrm{C}^{-1}\right), R_{\mathrm{n}}$ the net radiation above the canopy layer $\left(\mathrm{W} \mathrm{m}^{-2}\right), G$ the sensible heat storage $\left(\mathrm{W} \mathrm{m}^{-2}\right), \rho_{a}$ the density of the air $\left(\mathrm{kg} \mathrm{m}^{-3}\right), c_{p}$ the specific heat of dry air $\left(\mathrm{J} \mathrm{kg}^{-1}{ }^{\circ} \mathrm{C}^{-1}\right), g_{b}$ the boundary layer conductance for $\mathrm{H}_{2} \mathrm{O}\left(\mathrm{m} \mathrm{s}^{-1}\right)$, VPD the vapour pressure deficit (Pa), $\gamma$ the psychrometric constant $\left(\mathrm{Pa}^{\circ} \mathrm{C}^{-1}\right)$, and $g_{w}$ the total conductance for $\mathrm{H}_{2} \mathrm{O}\left(\mathrm{m} \mathrm{s}^{-1}\right)$ between the evaporating site and the bulk air (i.e. the series sum of the stomatal and boundary layer conductance) (Jones, 1992). The sunlit and shaded leaf area of each canopy layer is used to scale up to the level of the entire tree.

The sap flow submodel used in ANAFORE is based on the electrical analogon approach and is a simplified version of the water transport submodel of the RCGro model (Steppe et al., 2006). A diagram of the model is given in Fig. 1. This simplified dynamic flow and storage model uses three flow resistances and one capacitance. Transpiration of an individual tree and soil water potential are the inputs to calculate sap flow and water storage. The vertical water transport in the xylem can be described by Ohm's law:

$$
\begin{gathered}
T=\frac{\psi_{\text {stem }}-\psi_{\text {leaf }}}{R_{X}} \\
F_{\text {tree }}=\frac{\psi_{\text {soil }}-\psi_{\text {stem }}}{R_{X}}
\end{gathered}
$$

where $T$ is the canopy transpiration rate $\left(\mathrm{mg} \mathrm{s}^{-1}\right), F_{\text {tree }}$ is the sap flow in the stem $\left(\mathrm{mg} \mathrm{s}^{-1}\right), \psi_{\text {soil }}$ is the soil water potential (MPa), $\psi_{\text {stem }}$ is the water potential in the stem xylem and $R_{X}$ is the xylem flow resistance (MPa s mg ${ }^{-1}$ ). Both xylem flow resistances are assumed equal. Beside vertical water transport, internally stored water can contribute to the daily transpiration loss because of the hydraulic connection between the xylem and storage pools. This contribution depends on the magnitude of the hydraulic exchange resistance, $R_{S}\left(\mathrm{MPa} \mathrm{s} \mathrm{mg}^{-1}\right)$ that must be overcome when water flows from the storage compartments to the xylem to equilibrate the imbalance between water supply and demand during the day (Lhomme et al., 2001). Water flow to or from the storage pools $f_{\text {storage }}\left(\mathrm{mg} \mathrm{s}^{-1}\right)$ can be expressed as:

$f_{\text {storage }}=\frac{\psi_{\text {stem }}-\psi_{\text {storage }}}{R_{S}}$

where $\psi_{\text {storage }}$ is the water potential (MPa) in the storage compartment. Values of $f_{\text {storage }}$ are negative when water is withdrawn from the storage pool. Flow rates out of the xylem 
Table 2. Maximum water content, availability and storage water use of the 14 sampled Scots pine trees in the year 2000 at the experimental plot in Brasschaat, Belgium. All values are reported for individual trees. Maximum daily storage water use $\left(S T O_{\max }\right)$, maximum contribution of storage water to daily transpiration $\left(C O N_{\max }\right) . S T O_{\max }$ and $C O N_{\max }$ are maximum values for each tree over the entire studied period (27 May-18 October 2000). Maximum tree water content $\left(W_{\max }\right)$, maximum available tree water content $\left(A W_{\max }\right)\left(=W_{\max }-\operatorname{minimum} W\right.$ over the entire studied period), tree water content deficit threshold (WD).

\begin{tabular}{ccccccc}
\hline Tree \# & $\begin{array}{c}S T O_{\max } \\
\left(\mathrm{kg} \mathrm{day}^{-1}\right)\end{array}$ & $\begin{array}{c}C O N_{\max } \\
(\%)\end{array}$ & $\begin{array}{c}W_{\max } \\
(\mathrm{kg})\end{array}$ & $\begin{array}{c}A W_{\max } \\
(\mathrm{kg})\end{array}$ & $\begin{array}{c}A W_{\max } \\
\left(\% \text { of } W_{\max }\right)\end{array}$ & $\begin{array}{c}W D_{\text {threshold }} \\
\left(\% \text { of } W_{\max }\right)\end{array}$ \\
\hline 11 & 11.9 & 36.7 & 271 & 63 & 23.2 & 14.8 \\
12 & 12.9 & 35.2 & 214 & 44 & 20.6 & 13.8 \\
13 & 14.6 & 44.2 & 213 & 64 & 30.0 & 10.9 \\
14 & 13.4 & 43.1 & 171 & 54 & 31.6 & 18.2 \\
15 & 10.3 & 39.7 & 146 & 52 & 35.6 & 20.7 \\
16 & 8.8 & 39.0 & 114 & 32 & 28.1 & 15.8 \\
17 & 13.1 & 44.3 & 175 & 56 & 32.0 & 11.7 \\
21 & 12.8 & 41.5 & 258 & 53 & 20.5 & 7.7 \\
22 & 11.2 & 43.1 & 182 & 42 & 23.1 & 8.4 \\
23 & 7.7 & 30.2 & 168 & 30 & 18.9 & 9.9 \\
24 & 5.3 & 30.1 & 159 & 18 & 11.3 & 6.6 \\
25 & 6.0 & 32.0 & 150 & 25 & 16.7 & 9.6 \\
26 & 0.46 & 28.4 & 94 & 2 & 2.1 & 1.1 \\
27 & 11.7 & 44.6 & 160 & 57 & 35.6 & 20.6 \\
\hline
\end{tabular}

compartments can be derived from Kirchhoff's electric current law (Fig. 1):

$T=F_{\text {tree }}-f_{\text {storage }}$

The capacitance $C\left(\mathrm{mg} \mathrm{MPa}^{-1}\right)$ of the storage tissue can be defined as the ratio between the change in amount of water in the storage tissue and the change in water potential of the tissue (e.g. Hunt, 1991; Phillips et al., 2003).

$C=\frac{\Delta W}{\Delta \psi_{\text {storage }}}$

where $W$ is the water content of the tree (mg), corresponding to the total charge on the capacitor of an electrical circuit. The capacitance is considered here as a constant parameter per tree (Steppe et al., 2006).

The flow rate to or from the storage pool $f_{\text {storage }}$ described in Eq. (6) is equivalent to the change in water content of the storage pool:

$f_{\text {storage }}=\frac{\Delta W}{\Delta t}$

Our sap flow model combines the above set of algebraic and differential Eqs. (4-9). As initial conditions the water potential of the storage tissue is considered to be zero when the water content is maximal. The maximum water content $\left(W_{\max }, \mathrm{kg}\right.$ ) of the 14 pine trees (Table 2) was estimated by taking $40 \%$ of the stem volume (Steppe et al., 2006). The maximum available tree water content $\left(A W_{\max }, \mathrm{kg}\right)$ is calculated as the difference between $W_{\max }$ and the minimum of $W$ during the entire studied period. This minimum is not the absolute minimum, but the minimum of the considered period used as a baseline to calculate $A W_{\max }$. The tree water content deficit $(W D, \%)$ can be defined as the actual depleted fraction of $W_{\max }$.

The entire set of equations of the stomatal conductance, photosynthesis, transpiration and sap flow models is solved numerically for each time step, by an iteration procedure that converges to an equilibrium leaf water potential using the "golden section search" procedure (Press et al., 1996). The leaf water potential of the previous time step is used as an initial value to start the procedure.

As stated in Eq. (7), the storage water flow can be calculated from the difference between sap flow (measured or modeled) and modeled transpiration. Positive values of storage water flow indicate that water storage is being recharged. Negative values indicate that storage water is being used to fulfill the transpiration needs of the leaves. Each day, the use of storage water can be estimated from the curve of the storage water flow as the integrated area below the zero line. For the entire studied period the maximum daily storage water use $\left(S T O_{\max }, \mathrm{kg} \mathrm{day}^{-1}\right)$ and the maximum contribution of storage water to daily transpiration (\%) were calculated for each individual tree.

\subsection{Model parameterization and validation}

In a companion paper, the model was parameterized and validated using sap flow measurements and storage estimates for the 14 pine trees (Verbeeck et al., 2007). Parameter values (used in the equations to calculate stomatal conductance, sap flow, photosynthesis) are based on measurements at the 
Table 3. Parameter values used for the stomatal and the water storage model.

\begin{tabular}{lll}
\hline Symbol (units) & Parameter description & Value \\
\hline$a\left(\mathrm{~mol} \mathrm{H}_{2} \mathrm{O} \mathrm{m}^{-2} \mathrm{~s}^{-1}\right)$ & & \\
$a_{1}($ dimensionless$)$ & ABA sequestration rate & $1 \times 10^{-4}$ (Tardieu and Davies 1993) \\
$C\left(\mathrm{mg} \mathrm{MPa}^{-1}\right)$ & Empirical constant (parameter combination) & Calibrated \\
$D_{0}\left(\mathrm{kPa}^{2}\right)$ & Capacitance of storage compartment & Calibrated \\
$b\left(\mathrm{~mol} \mathrm{CO}_{2} \mathrm{~m}^{-2} \mathrm{~s}^{-1}\right)$ & Empirical constant (parameter combination) & 1.0 (Verbeeck et al., 2007) \\
$R_{S}\left(\mathrm{MPa} \mathrm{s} \mathrm{mg}^{-1}\right)$ & Empirical constant & $5.0 \times 10^{-6}$ (Verbeeck et al., 2007) \\
& Hydraulic exchange resistance between & 0.0013 (Verbeeck et al., 2007) \\
$R_{X}\left(\mathrm{MPa} \mathrm{s} \mathrm{mg}^{-1}\right)$ & xylem and storage compartment & \\
$V_{w}\left(\mathrm{~m}^{3} \mathrm{~mol}^{-1} \mathrm{H}_{2} \mathrm{O}\right)$ & Xylem flow resistance & Calibrated \\
$\beta\left(\mathrm{m}^{3} \mathrm{~mol}^{-1} \mathrm{ABA}^{-}\right)$ & Partial molal volume of water & $18 \times 10^{-6}$ \\
$\delta\left(\mathrm{MPa}^{-1}\right)$ & ABA sensitivity parameter & $1.48 \times 10^{-4}$ (Tardieu and Davies, 1993) \\
$\lambda_{\text {root }}$ & ABA sensitivity parameter & -2 (Tardieu and Davies 1993) \\
$\left(\mu \mathrm{mol} \mathrm{ABA} \mathrm{MPa}^{-1} \mathrm{~m}^{-2} \mathrm{~s}^{-1}\right)$ & ABA synthesis constant of roots & $4.0 \times 10^{-6}$ (Dewar, pers. comm.) \\
$\lambda_{\text {leaf }}$ & ABA synthesis constant of leaves & $1.0 \times 10^{-6}$ (Dewar, pers. comm.) \\
$\left(\mu \mathrm{mol} \mathrm{ABA} \mathrm{MPa}^{-1} \mathrm{~m}^{-2} \mathrm{~s}^{-1}\right)$ & & \\
\hline
\end{tabular}

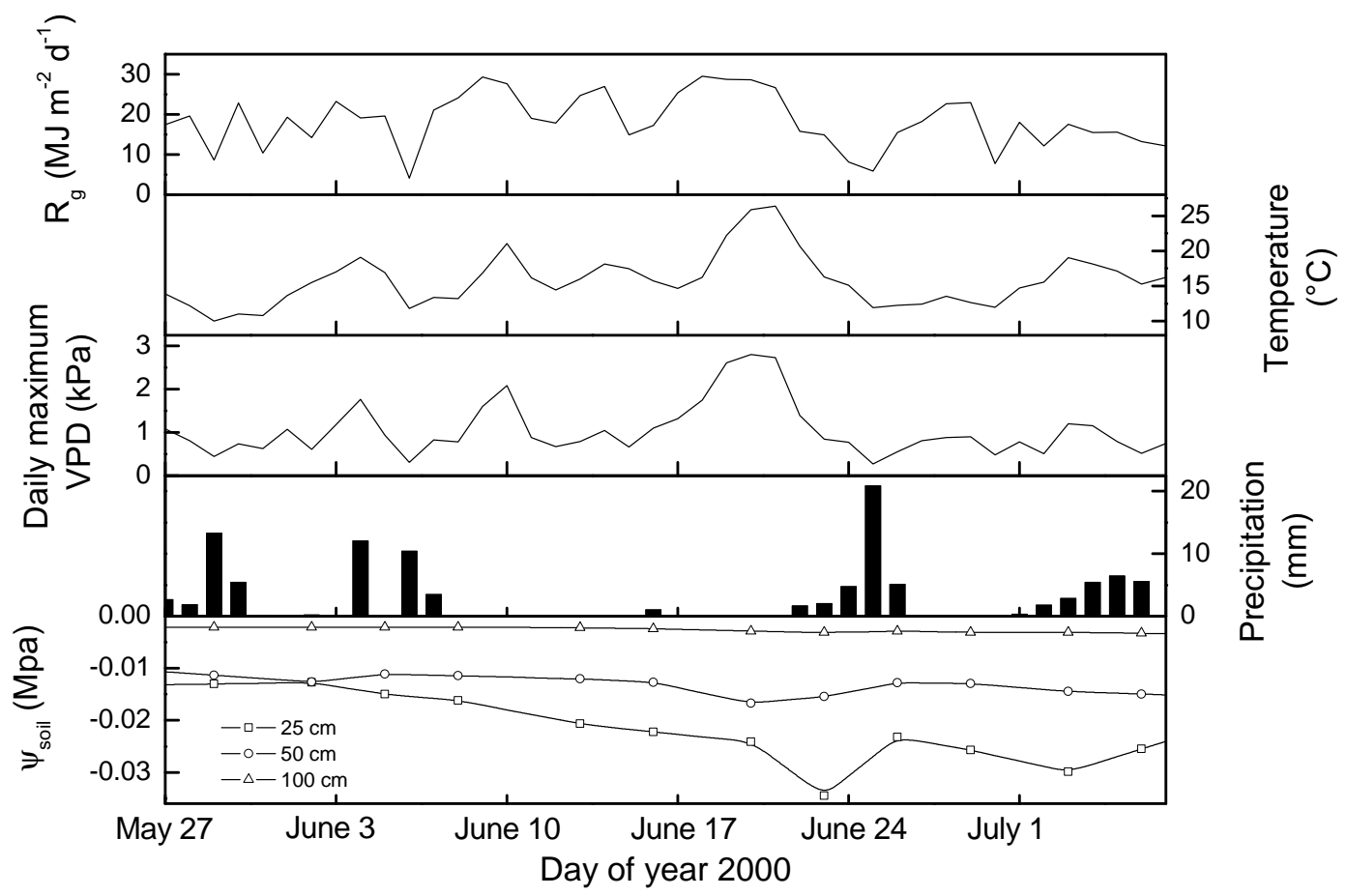

Fig. 2. Climatic conditions during the studied period (27 May-7 July 2000): daily incoming solar radiation ( $\left.R_{g}\right)$, mean daily temperature, daily maximum vapour pressure deficit (VPD), precipitation and soil water potential $\left(\psi_{\text {soil }}\right)$.

Brasschaat site or on general parameters from the literature (Sampson et al., 2006; Verbeeck et al., 2007). Parameter values of the stomatal and the water storage model are given in Table 3. A subset of three parameters $\left(a_{1}, C\right.$ and $\left.R_{X}\right)$ was selected to be calibrated with half-hourly sap flow data (Verbeeck et al., 2007) using the simplex algorithm (Nelder and Mead, 1965). The validation of the model revealed that a calibration using only the first two weeks of sap flow data yielded parameter values that were valid for the rest of the growing season (145 days of data) (Verbeeck et al., 2007). Nevertheless, for the present study we tested a recalibration of the model every two weeks of the growing season. Although considerable seasonal variation was found (a standard deviation of up to $20 \%$ of the mean for $a_{1}$ and $R_{X}$ and up to 
Table 4. Calibrated values for parameters $a_{1}$ (empirical constant of stomatal model), $C$ (capacitance of storage compartment) and $R_{X}$ (xylem flow resistance) for different trees based on sap flow data of two weeks (27 May-9 June 2000).

\begin{tabular}{cccc}
\hline Tree Nb. & $a_{1}(-)$ & $C\left(\times 10^{6} \mathrm{mg} \mathrm{MPa}^{-1}\right)$ & $R_{X}\left(\mathrm{MPas} \mathrm{mg}^{-1}\right)$ \\
\hline 11 & 3.73 & 23.7 & 0.00150 \\
12 & 4.38 & 32.9 & 0.00129 \\
13 & 4.45 & 50.5 & 0.00172 \\
14 & 3.89 & 43.5 & 0.00167 \\
15 & 2.17 & 69.0 & 0.00139 \\
16 & 2.24 & 37.8 & 0.00147 \\
17 & 3.25 & 46.5 & 0.00178 \\
21 & 3.13 & 48.6 & 0.00156 \\
22 & 3.07 & 34.4 & 0.00182 \\
23 & 2.04 & 51.7 & 0.00090 \\
24 & 1.34 & 38.4 & 0.00097 \\
25 & 1.42 & 54.5 & 0.00099 \\
26 & 1.59 & 49.1 & 0.00083 \\
27 & 2.63 & 55.6 & 0.00179 \\
\hline
\end{tabular}

$70 \%$ for $C$ ), the two-weekly parameterization yielded only a slightly better fit to the sap flow measurements, and no clear trends (seasonal or climatic) could be found in the parameters. Therefore, constant parameters were used for the entire growing season (Table 4).

\subsection{Site conditions}

For the analysis in this study we selected six weeks (27 May7 July 2000) of data that contained sunny days with high sap flow rates as well as cloudy days with lower sap flow. Moreover, the 3rd and 4th week had almost no precipitation and the 4th week showed a peak in temperature and VPD (Fig. 2).

Although the soil water potential reached the lowest value of the growing season (23 June) due to a fortnight without precipitation, there was never severe soil water stress for the trees. Soil water potential dropped only once below field capacity $(-0.03 \mathrm{MPa})$ in the top soil layer $(25 \mathrm{~cm})$. The deeper layers, which can be easily reached by the roots of the pines, were always above field capacity. A regression showed that soil water content could only explain less than $4 \%$ of the variability in the daily sap flow measurements. This could be expected because transpiration of woody species remains unaffected until the soil water fraction has decreased to a level between $23 \%$ and $32 \%$ of field capacity (Sinclair et al., 2005). However, soil water fraction is not the only factor influencing water availability for tree. Several other factors can play a role (e.g. level of the water table, hydraulic lift,...). Nevertheless, the absence of severe soil water stress for the pine trees during the study period gave the opportunity to investigate the effects of atmospheric drought.

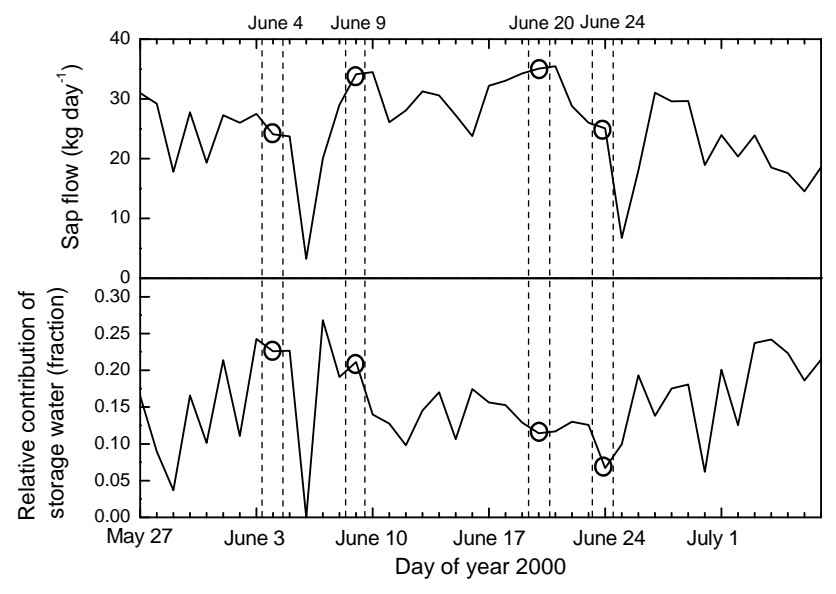

Fig. 3. Day to day variation of the measured sap flow of pine \#23 and the relative contribution of storage water use to daily transpiration. Four typical days were selected (4 June, 9 June, 20 June, 24 June). 4 June and 9 June before the period of high VPD, 20 June during the period of high VPD and 24 June shortly after that period. These four days were paired as such that both pairs had two days with equal measured daily sap flow, but with contrasting storage water use. The first pair (4 June and 24 June) contained the days with a moderate sap flow and entirely different climatic conditions. The second pair (9 June and 20 June) was chosen to examine the effect of high VPD. Both days had similar high incoming radiation, but the temperature and VPD of 20 June were much higher as compared to 9 June.

2.7 Selection of typical days to analyze microclimate effects

Based on the daily measured sap flow and the modeled contribution of storage water to daily transpiration of all pine trees (example in Fig. 3 for pine \#23) we selected four typical days for a detailed analysis of the storage water use: 4 June and 9 June before the period of high VPD, 20 June during the period of high VPD and 24 June shortly after that period. These four days were paired as such that both pairs had two days with equal measured daily sap flow, but with contrasting storage water use. The first pair (4 June and 24 June) contained the days with a moderate sap flow and entirely different climatic conditions. 4 June had high incoming radiation, temperature and VPD. In contrast, on 24 June incoming radiation, temperature and VPD were low. The second pair (9 June and 20 June) was chosen to examine the effect of high VPD. Both days had similar high incoming radiation, but the temperature and VPD of 20 June were much higher as compared to 9 June. 


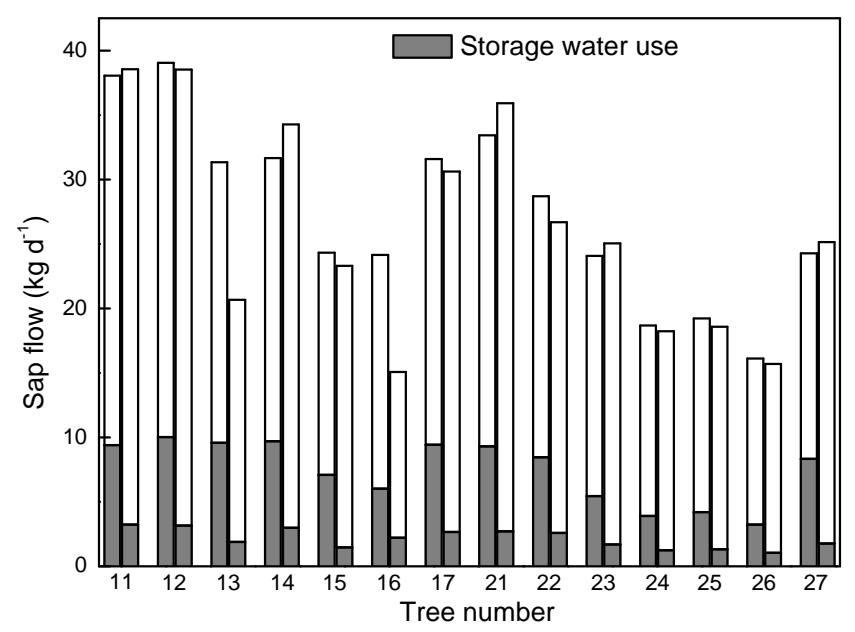

Fig. 4. Comparison of measured daily sap flow and storage water use between 4 June (left bars) and 24 June (right bars) for all 14 pine trees.

\section{Results and discussion}

\subsection{Variability of storage water use}

The pine trees showed a considerable day-to-day variation in the relative contribution of storage water use to daily transpiration (Fig. 3). The variation in absolute daily use of stored water was even larger (data not shown). In a companion paper (Verbeeck et al., 2007) we showed that the general seasonal trend of daily storage water use is similar to that of the daily transpiration or sap flow. In contrast to these similar seasonal trends, the day-to-day patterns of measured sap flow and relative contributions of stored water to daily transpiration differ a lot (Fig. 3). Days with an equal amount of sap flow had very different amounts of storage water use. Comparing 4 June with 24 June for all trees shows that, except for trees \#13 and \#16, all trees had a similar amount of sap flow on both days, but all trees showed a much lower storage water use on 24 June (Fig. 4). The absolute amount of storage water use varied from tree to tree and could be linked to the dimensions of the trees, as previously described (Verbeeck et al., 2007).

Maximum use of stored water over the growing season varied among trees from 0.46 to $14.6 \mathrm{~kg} \mathrm{day}^{-1}$ (Table 2). The upper bound of this range corresponds well to the average value of $14 \mathrm{~kg}$ that Köstner et al. (1998) found for easily available water in Picea abies trees. The maximum contribution of the storage water to daily transpiration varied between 28 and $45 \%$. These values fall within the wide range of values that can be found in the literature: ranging from 1 up to $50 \%$ (Čermák et al., 2007) or even up to $65 \%$ (Zweifel et al., 2001).

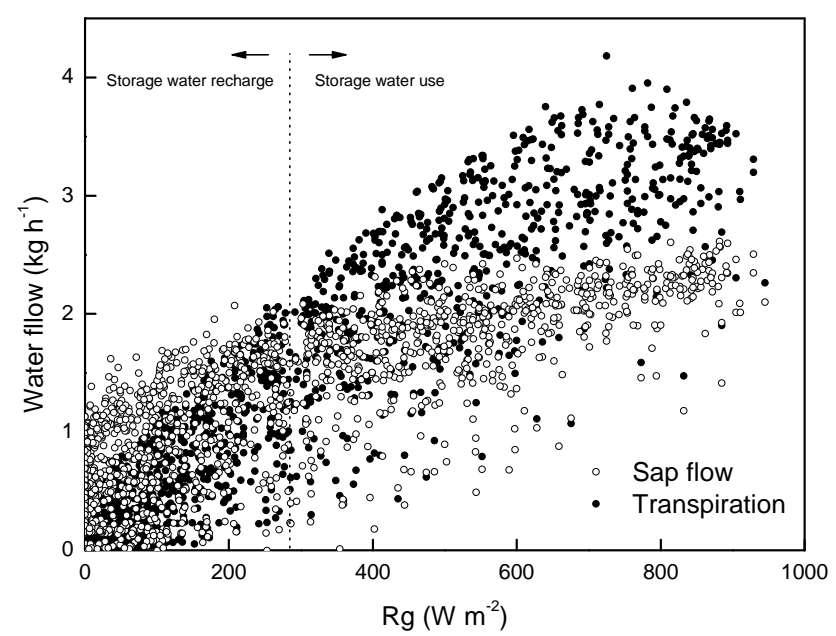

Fig. 5. Half-hourly values of measured sap flow (o) and modeled transpiration $(\bullet)$ versus incoming solar radiation $\left(R_{g}\right)$ for pine \#23 (27 May-18 October 2000).
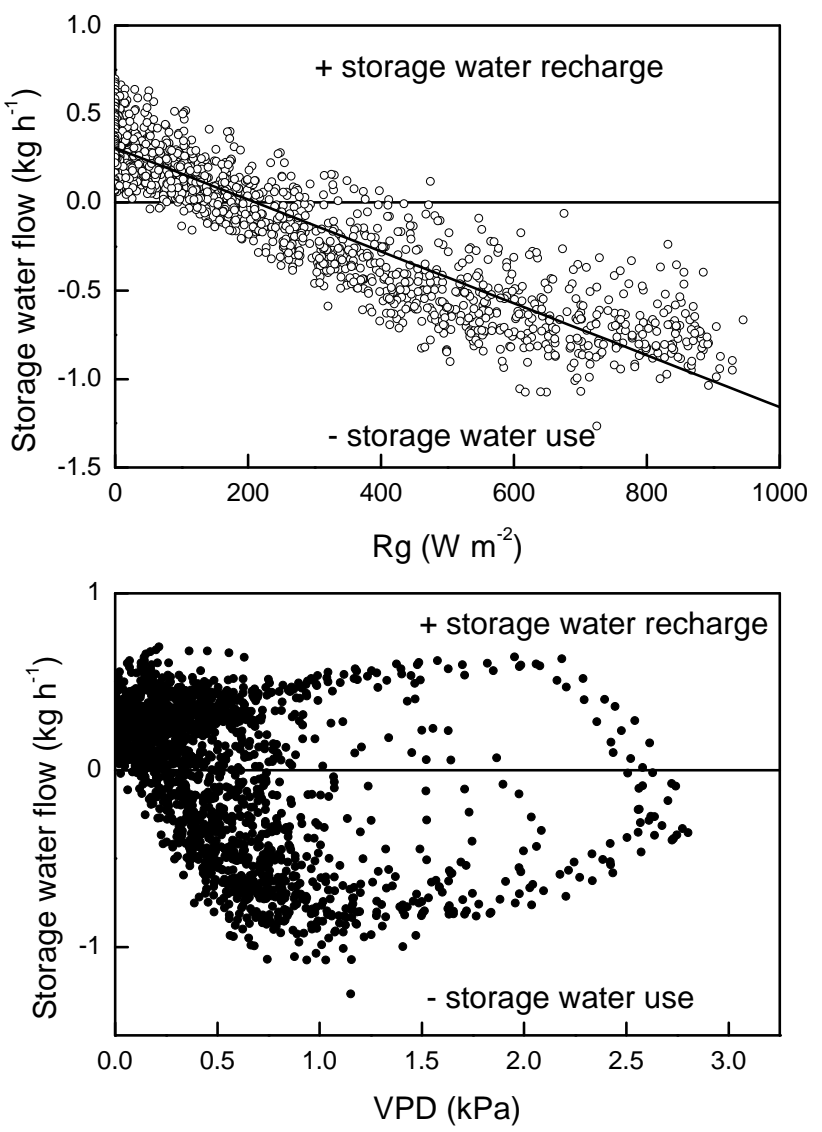

Fig. 6. Half-hourly values of modeled storage water flow versus (top panel) incoming solar radiation $\left(R_{g}\right)$ and (bottom panel) vapour pressure deficit (VPD), for pine \#23 (27 May-18 October 2000). 


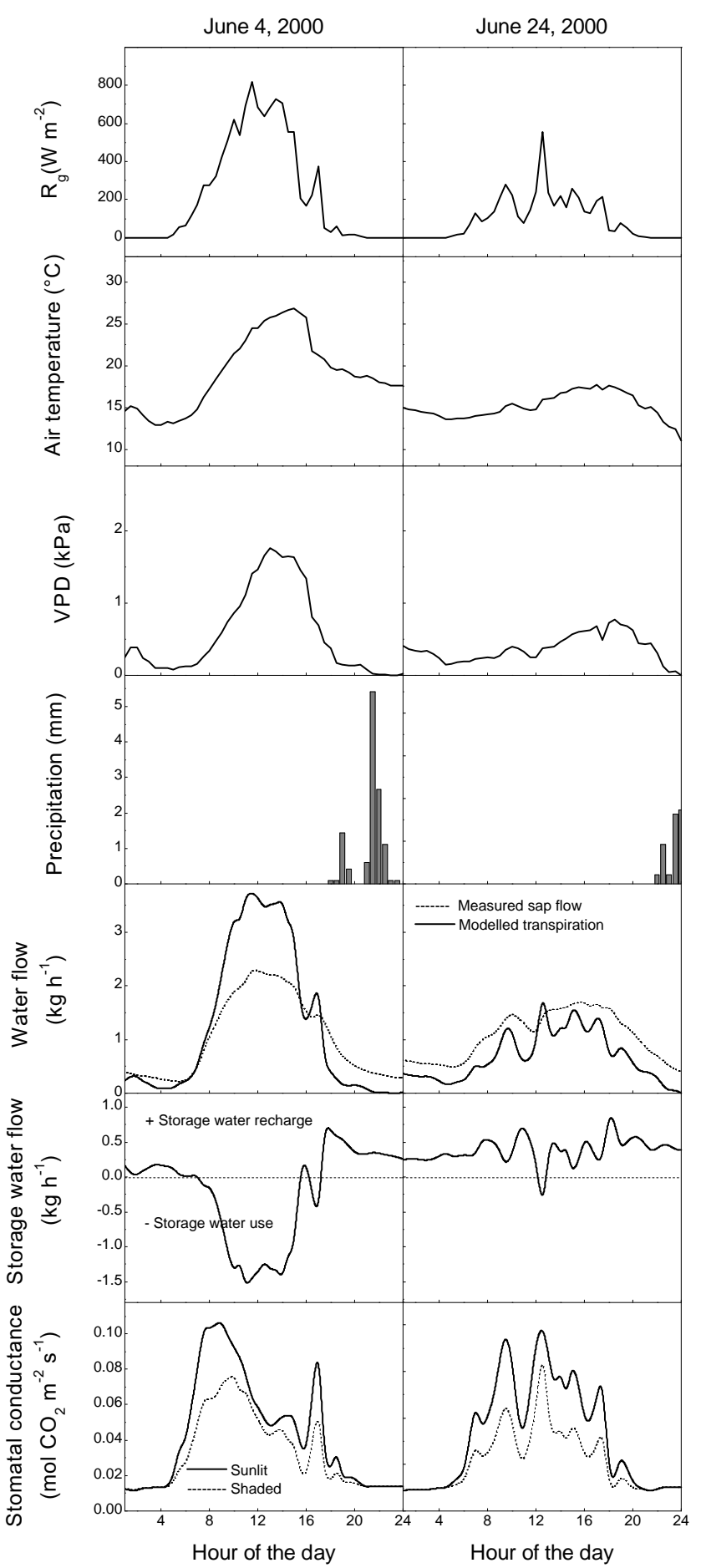

Fig. 7. Comparison of diurnal patterns during two days (4 June and 24 June 2000): climate, water flow and modeled stomatal conductance ( $g_{s}$, given per square meter of sunlit or shaded leaf at the top of the canopy) of pine \#23. ( $R_{g}=$ incoming solar radiation; VPD = vapour pressure deficit)

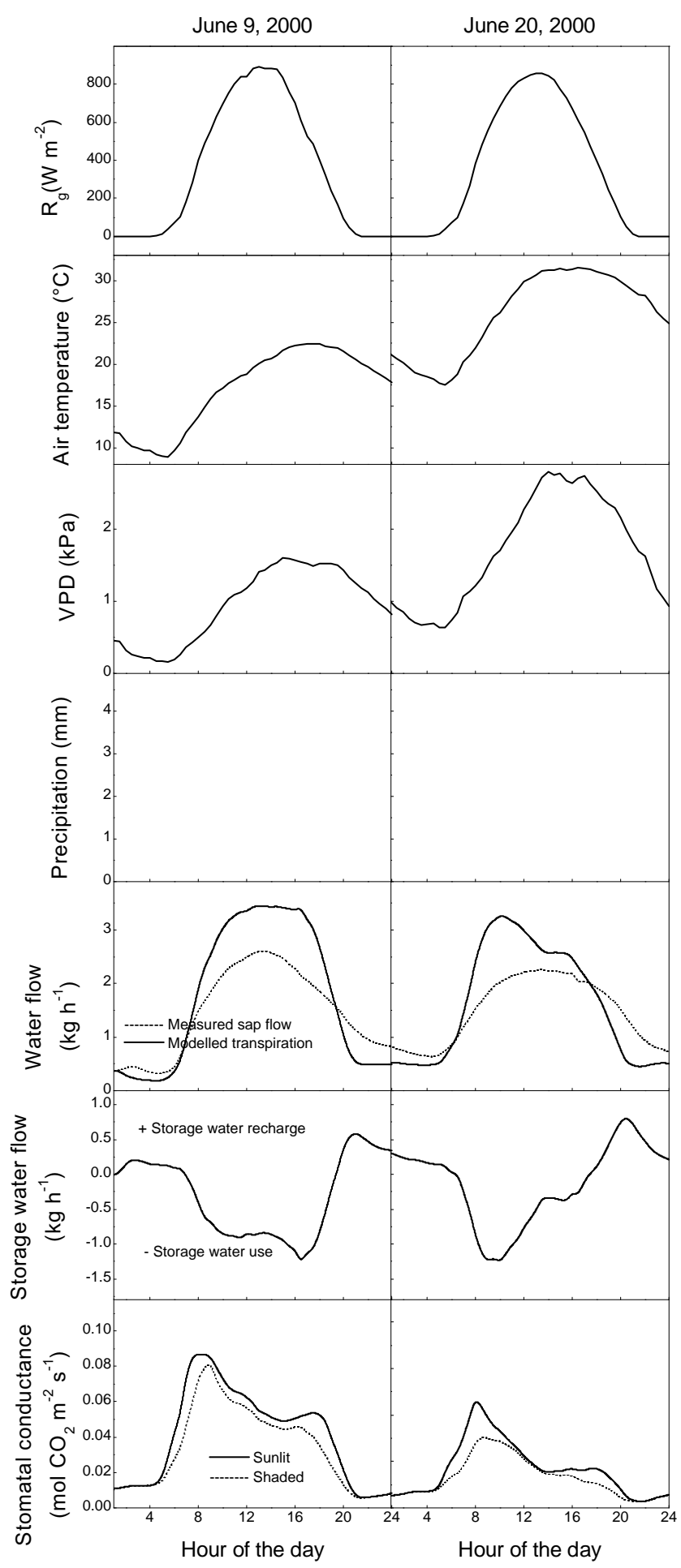

Fig. 8. Comparison of diurnal patterns during two days (9 June and 20 June 2000): climate, water flow and modeled stomatal conductance $\left(g_{s}\right.$, given per square meter of sunlit or shaded leaf at the top of the canopy) of pine \#23. ( $R_{g}=$ incoming solar radiation; $\mathrm{VPD}=$ vapour pressure deficit) 


\subsection{Radiation effects}

The different response of sap flow and transpiration to radiation (Fig. 5), is one of the mechanisms that determines the use of water from the storage compartments. With higher radiation the increase in sap flow is less steep than the increase in transpiration due to the buffering effect of storage water. Storage water use was high at high rates of incoming radiation and storage water recharge took place when incoming radiation was low (Fig. 6a). On the other hand, when the storage water flow was plotted against VPD (Fig. 6b) or temperature (data not shown) the effect of these factors on storage water use was less pronounced than the effect of incoming radiation.

Two days with similar measured daily sap flow but with totally different climatic conditions were compared (Fig. 7). 4 June was warm and sunny and 24 June was cool and cloudy with an incoming radiation of 19.1 and $8.2 \mathrm{MJ} \mathrm{m}^{2}$ day $^{-1}$, respectively. These differences in microclimate and thus in transpiration caused a large difference in storage water use (e.g. 13.3 and $1.0 \mathrm{~kg} \mathrm{day}^{-1}$, respectively for pine tree \#23). Although modeled stomatal conductance was high during the whole day on 24 June, low radiation and VPD kept the transpiration rates small. In this extreme case, the transpiration during the cloudy day (24 June) was higher than the sap flow only during one short period around midday, which means that storage water was used only during this short period and that during the rest of the day storage recharge was taking place.

\subsection{Effects of vapour pressure deficit}

The effects of radiation and VPD are highly correlated and difficult to separate. To illustrate the effect of VPD on storage water use, we compared two days (9 June and 20 June) with a similar measured sap flow and equal incoming radiation (29.3 and $28.6 \mathrm{MJ} \mathrm{m}^{2}$ day $^{-1}$, respectively), but different VPD (peak values of 1.6 and $2.8 \mathrm{kPa}$, respectively). This comparison showed that atmospheric drought is a second important driver influencing storage water use via transpiration (Fig. 8). It is clear that on 20 June (high VPD) stomatal closure in the afternoon was much stronger, which reduced transpiration and thus use of storage water. Furthermore, the refilling of the storage pool was higher on 20 June. The response of stomates to VPD has been reported by several authors (e.g. Monteith, 1995; Martin et al., 1997; Irvine et al., 1998; Oren et al., 1999a; Gao et al., 2002; Motzer et al., 2005). It is recognized as one of the most important sources of variation in stomatal conductance, but the mechanism of the response is still unclear (Bunce, 1997; 2006; Whitehead, 1998). The modeled stomatal conductance values of this study are consistent with other data for Scots pine (Stewart, 1988; Irvine et al., 1998).

The VPD effect is even better illustrated by the typical hysteresis patterns in Fig. 9. The hysteresis is caused by time shifts between the diurnal patterns of radiation, VPD, temperature, transpiration and sap flow. Analysis of these patterns gives a better insight into the interactions between climate and the diurnal patterns of water flow in the tree.

The relation between water flow and VPD shows a clockwise hysteresis. On days with moderate VPDs, there is a typical plateau at VPDs close to $1.5 \mathrm{kPa}$ (Fig. 9iii), while on days with extreme high VPD (Fig. 9iv) transpiration even declined at VPDs above $1.5 \mathrm{kPa}$. On June 9 (Fig. 9iii) transpiration increased until $14 \mathrm{~h}$ but on 20 June (Fig. 9iv) transpiration started decreasing at $10 \mathrm{~h}$ due to the high VPD values that were already reached. Due to the buffering effect of the storage water, this decrease was not observed in the sap flow measurements.

The widths of the hysteresis loops between transpiration and VPD were larger than the widths of the loop of sap flow versus VPD (Fig. 9). This typical pattern of clockwise hysteresis has been found by several authors (Meinzer et al., 1997, 1999; Ewers et al., 2005; Motzer et al., 2005).

Plotting sap flow versus solar radiation typically produces a counter-clockwise hysteresis (Meinzer et al., 1997; Ewers et al., 2005). We also observed this on days with moderate VPD. However, in case of high VPD we found a clockwise hysteresis (Fig. 9ii). The decrease of transpiration starting around $10 \mathrm{~h}$ in the morning caused this clockwise pattern. In contrast, during the sunny day with low VPD (Fig. 9i), transpiration increased until $14 \mathrm{~h}$. This illustrates the high impact of VPD on the diurnal pattern of water flow within a tree.

The large discrepancy between sap flow at the stem base and transpiration at the leaf level indicates that sap flow measurements should not be used to calculate diurnal patterns of canopy conductance by inverting the Penman-Monteith equation without taking the possible time-lag into account. Sap flow can only be used as a measure for diurnal transpiration if the measurements are corrected for the time lag with transpiration. A commonly used method to account for the time lag is to artificially shift the sap flow time series to maximize correlation with VPD or radiation (Oren et al., 1999b; Ford et al., 2005).

Contrary to the expectation that trees would rely more on their storage water in periods of atmospheric drought, we found in this study that the storage water use did not increase with atmospheric drought. However, in conditions of high soil water availability, storage water use was mainly driven by transpiration. Therefore, the hypothesis of Phillips et al. (2003) that storage water use increases with drought, only holds for soil water stress and not for atmospheric drought. According to our results, atmospheric drought did not induce an extra use of storage water. The use of storage water is not an extra advantage for trees in overcoming atmospheric drought in well-watered soils. Nonetheless, storage water contributes substantially to daily transpiration, irrespective of the climatic conditions. These results confirm that stored water plays an important role not only during periods of 


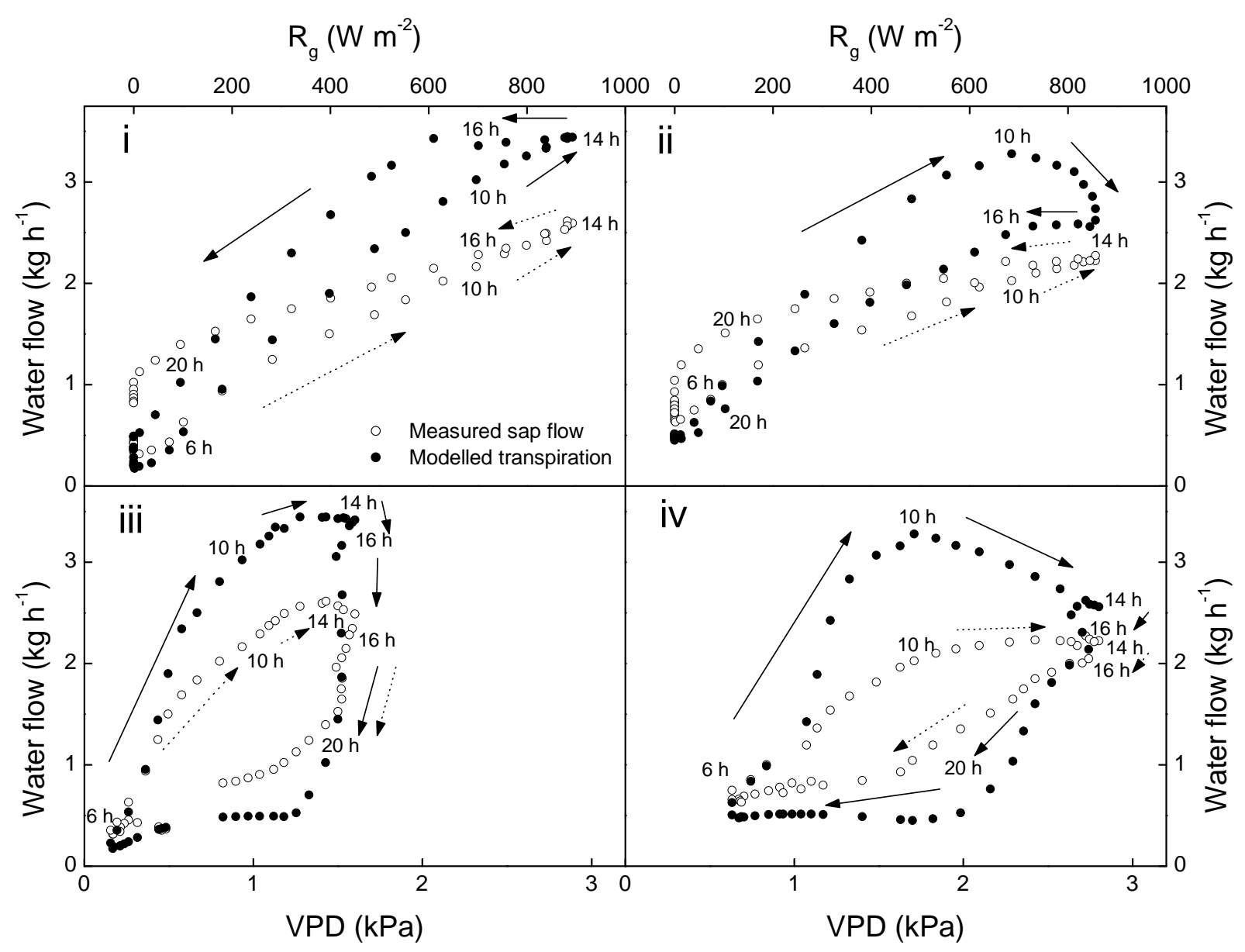

Fig. 9. Hysteris patterns of sap flow and transpiration versus solar radiation $\left(R_{g}\right)$ (i and ii) and versus vapour pressure deficit (VPD) (iii and iv) for pine \#23 on 9 June and 20 June (2000), respectively.

drought, but whenever water transport occurs within the tree (Zweifel et al., 2001). These last mentioned authors found that even in well-watered soils the tree water reserves were depleted every morning.

\subsection{Constraints by tree water content deficit}

Due to the use and recharge of stored water, the internal tree water content $(W)$ fluctuated daily. The daily minimum tree water content was strongly correlated with daily solar radiation and by daily maximum VPD (e.g. for pine \#23 in Fig. 10). The total observed amount of stored water available for transpiration $\left(A W_{\max }\right)$ varied among trees from 2 to $64 \mathrm{~kg}$. The available storage water ranged between $2 \%$ and $36 \%$ of the total tree water content (Table 2).

Besides the diurnal fluctuations of tree water content, there was also a considerable day-to-day variation in daily mean tree water content, due to the net daily storage water use or recharge. When the relative contribution of storage water use to transpiration was plotted against daily mean values of the water deficit in the tree (WD) (Fig. 11), it became clear that the tree water content puts a constraint on the maximum possible contribution to the daily transpiration. In other words, the increase of transpiration was higher than the increase of storage water use with tree water content deficit.

On the other hand, the absolute amount of storage water use continues to increase with increasing tree water content deficit, until a maximum is reached (Fig. 12). Beyond this threshold of tree water content deficit ( $\left.W D_{\text {threshold }}\right)$, a further depletion of the storage pool is more difficult due to the low water potential in the storage compartment, resulting in a lower storage water use. The threshold for tree water content deficit varied considerably among the 14 individual trees, ranging from $1 \%$ to $21 \%$ (Table 2).

Over the considered period without soil water stress, the simulations showed that the pine trees were able to refill the water storage pool that was depleted due to net daily storage water use. This is an indication that permanent cavitation was probably not taking place during the considered period. 

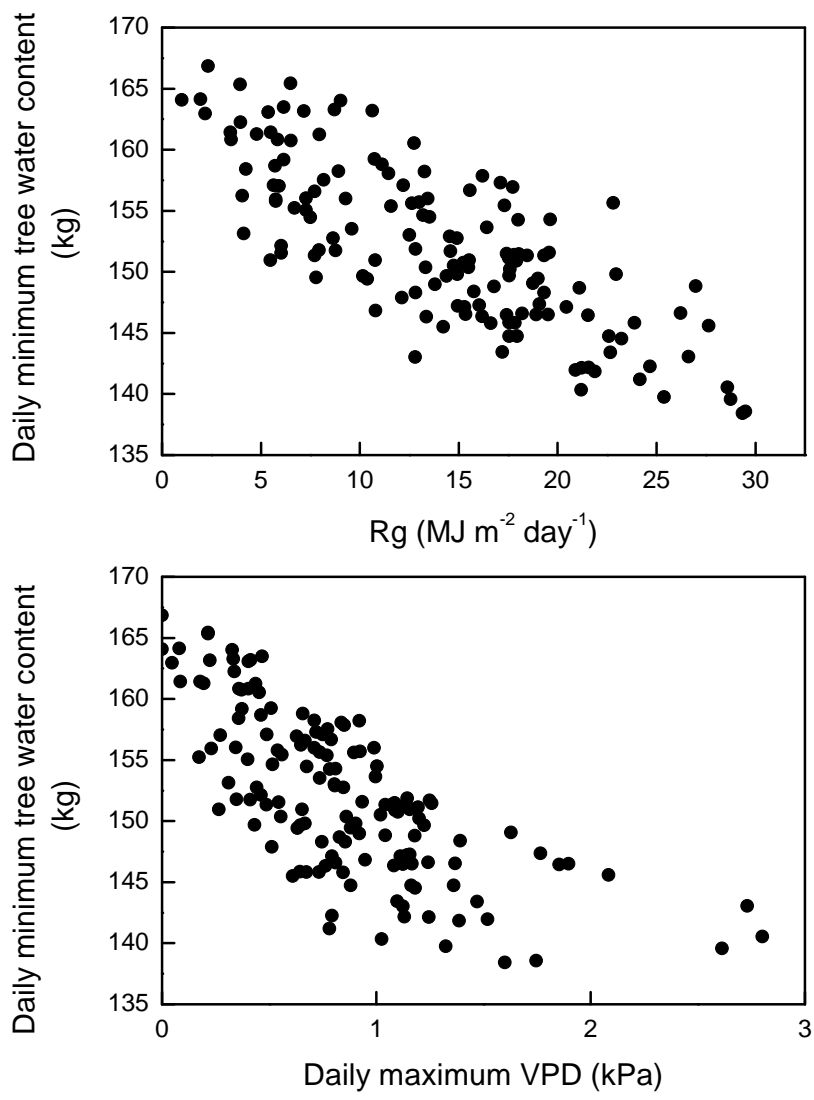

Fig. 10. Daily minimum values of tree water content plotted versus incoming solar radiation $\left(R_{g}\right)$ (top panel) and versus daily maximum vapour pressure deficit (VPD) (bottom panel). Data from pine \#23 for the period 27 May-18 October 2000.

\subsection{Limitations of the model analysis}

The above analysis shows that the ANAFORE model is a useful tool to analyse storage water use and its influencing factors. Nevertheless, the models' general structure and several specific assumptions put limits on the use of the model and the power of the analysis.

The simple representation of the hydraulic system of a tree (Fig. 1) does not give the possibility to study in detail all of the internal physical factors that influence storage water use. Our electrical analogon model is a convenient simplification of reality, but the assumptions and simplifications introduce some errors. For example, in reality the xylem compartment and the storage compartment are partly confounded and share common properties that are not taken into account in the model. Other important processes are not explicitely modelled in our approach e.g. embolism (Hölttä et al., 2002) and, xylem diameter fluctuations (Perämäki et al., 2005). More detailed sap flow models (e.g. Früh and Kurth, 1999) will have the potential to conduct more detailed analyses. But a limited dataset like ours (sap flow and meteorological data) will probably not be sufficient to identify all parameters in-

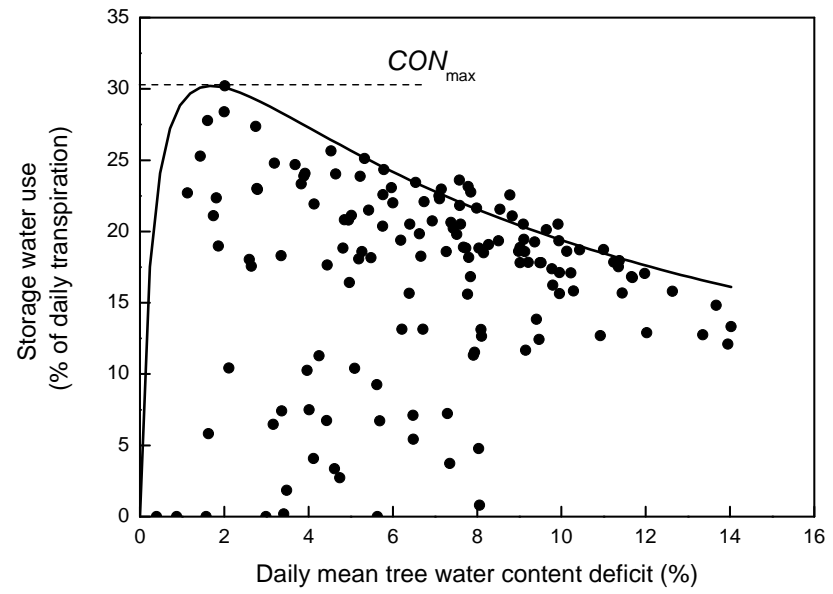

Fig. 11. Contribution of storage water use to daily transpiration versus mean daily tree water content deficit (\%). The data were divided in categories per $0.5 \%$ tree water content deficit. The curve was fitted through the maxima of each category. Data from pine \#23 for the period 27 May-18 October 2000. $C O N_{\max }=$ maximum contribution of storage water to transpiration.

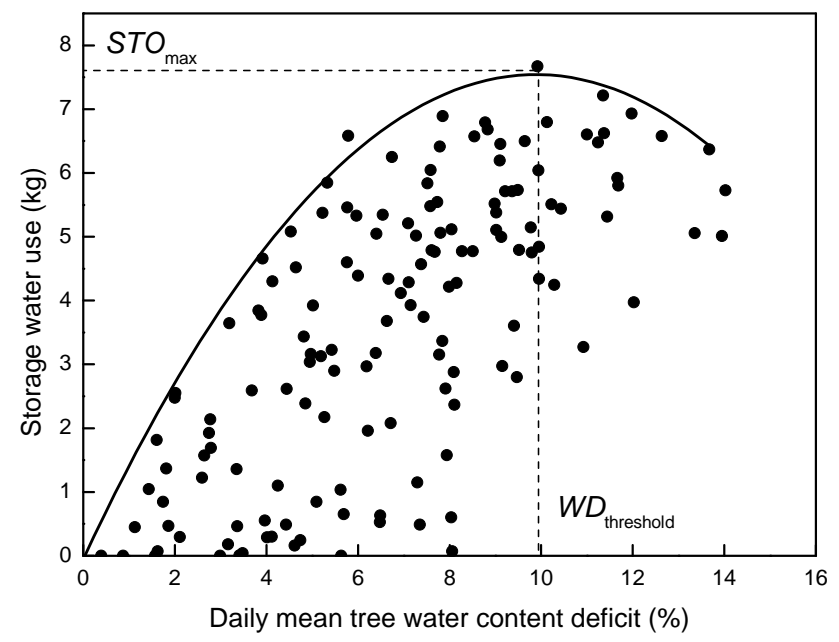

Fig. 12. Storage water use $(\mathrm{kg})$ versus mean daily tree water content deficit (\%). The data were divided in categories per $0.5 \%$ tree water content deficit. The curve was fitted through the maxima of each category. Data from pine \#23 for the period 27 May-18 October 2000. $S T O_{\max }=$ maximum daily storage water use; $W D_{\text {threshold }}=$ tree water content deficit threshold.

cluded in such complex models.

Moreover, even with the simple flow model used in this study, problems of parameter identifiability appear when only a limited dataset is available (Verbeeck et al., 2007). More complex models can therefore only be applied on a very limited amount of well equipped measurement sites.

Flow resistances and the capacitance $(C)$ were assumed constant, which is a simplification of reality. Without soil water stress (no cavitation), we can assume a constant xylem 
flow resistance. Nevertheless, in case of soil water stress this assumption is no longer valid, because the xylem flow resistance will increase due to cavitation. Also $C$ will vary over time (Scholz et al., 2007). The recalibration of our model showed indeed a large seasonal variability of $C$. Difference in capacitance can be due to differences in the biophysical properties of the storage tissues and/or due to differences in the size of the storage compartment (Scholz et al., 2007).

In addition, the time step of the meteorological data put a constraint on the accuracy of the storage water use estimates. Also the accuracy of our conclusions concerning time-lags between onset of transpiration of the leaves and onset of sap flow is restricted by the time step of the meteorological data (in this case $30 \mathrm{~min}$ ). The moment when a pine tree switches between storage use and storage refilling can only be estimated with an accuracy of a half hour.

\section{Conclusions}

Relations between water flow, storage water use and climatic drivers were analysed in this study. As expected, solar radiation is the main atmospheric driver of transpiration, and thus also of sap flow and storage water use. Nevertheless, the dayto-day patterns of measured sap flow and storage water use could be quite different, even when solar radiation was equal. VPD was the main atmospheric driver of these differences. In conditions of high soil water availability and atmospheric drought, trees did not rely more on their storage water. In contrast, when VPD was high, closing stomata caused low transpiration and low storage water use. The daily minimum tree water content was lower in periods of high VPD, but the reserves were not completely depleted after the first day of high VPD, due to refilling during the night.

Nevertheless, the tree water content deficit was a third important factor influencing storage water use. When storage compartments were depleted beyond a threshold, storage water use became limited due to low water potential in the storage compartments. Also the maximum relative contribution of storage water to daily transpiration was constrained by an increasing tree water content deficit.

The next step in the development of the model will be the analysis of effects of soil water stress on storage water use. Maintenance of considerable transpiration rates after soil drying often depends on the availability of water in deeper soil layers, but is also hypothesized to be a result from contributions of storage water to transpiration (Sinclair et al., 2005). Future analysis with the ANAFORE model might enable us to test this hypothesis.

Acknowledgements. This research was supported by: (1) the European Commission, Directorate-General Research, Sixth Framework Programme (Priority area of Global Change and Ecosystems), Carbo-Europe IP as contract no. GOCE-CT-2003-505572; (2) the Bilateral Exchange Programme of the Flemish Community and the Czech Republic (Contract No. BWS-BOF-2006); and (3) the Ministry of the Flemish Community, (VLINA 99/6). Kathy Steppe gratefully acknowledges a Postdoctoral Fellow grant of the Research Foundation - Flanders (FWO). The authors wish to thank Marc Schuermans (AMINAL) and Fred Kockelbergh (UA) for logistic support.

Edited by: F. X. Meixner

\section{References}

Baeyens, L., Van Slycken, J., and Stevens, D.: Description of the soil profile in Brasschaat, Internal research paper, Institute for Forestry and Game Management, Geraardsbergen, Belgium, 1993.

Bhaskar, R. and Ackerly, D. D.: Ecological relevance of minimum seasonal water potentials, Physiol. Plant., 127, 353-359, 2006.

Bunce, J. A.: Does transpiration control stomatal responses to water vapour pressure deficit?, Plant Cell Environ., 20, 131-135, 1997.

Bunce, J. A.: How do leaf hydraulics limit stomatal conductance at high water vapour pressure deficits?, Plant Cell Environ., 29, 1644-1650, 2006.

Carrara, A., Kowalski, A. S., Neirynck, J., Janssens, I. A., Curiel Yuste, J., and Ceulemans, R.: Net ecosystem $\mathrm{CO}_{2}$ exchange of mixed forest in Belgium over 5 years, Agric. For. Meteorol., 119, 209-227, 2003.

Čermák, J., Riguzzi, F., and Ceulemans, R.: Scaling up from the individual trees to the stand level in Scots pine: 1. Needle distribution, overall crown and root geometry, Ann. For. Sci., 55, 63-88, 1998.

Čermák, J., Kučera, J., and Nadezhdina, N.: Sap flow measurements with some thermodynamic methods, flow integration within trees and scaling up from sample trees to entire forest stands, Trees, 18, 529-546, 2004.

Čermák, J., Kučera, J., Bauerle, W. L., Phillips, N., and Hinckley, T. M.: Tree water storage and its diurnal dynamics related to sap flow and changes in stem volume in old-growth Douglas-fir trees, Tree Physiol., 27, 181-198, 2007.

Chuang, Y.-L., Oren, R., Bertozzi, A. L., Phillips, N., and Katul, G. G.: The porous media model for the hydraulic system of a conifer tree: Linking sap flux data to transpiration rate, Ecol. Model., 191, 447-468, 2006.

Curiel Yuste, J., Konôpka, B., Janssens, I. A., Coenen, K., Xiao, C. W. and Ceulemans, R.: Contrasting net primary productivity and carbon distribution between neighboring stand of Quercus robur and Pinus sylvestris, Tree Physiol., 25, 701-712, 2005.

Dewar, R. C.: The Ball-Berry-Leuning and Tardieu-Davies stomatal models: synthesis and extension within a spatially aggregated picture of guard cell function, Plant Cell Environ., 25, 13831398, 2002.

Ewers, B. E., Gower, S. T., Bond-Lamberty, B., and Wang, C. K.: Effects of stand age and tree species on canopy transpiration and average stomatal conductance of boreal forests, Plant Cell Environ., 28, 660-678, 2005.

Farquhar, G. D., Von Caemmerer, S., and Berry., J.A.: A biochemical model of photosynthetic $\mathrm{CO}_{2}$ assimilation in leaves of $\mathrm{C} 3$ species, Planta, 149, 78-90, 1980.

Ford, C. R., Goranson, C. E., Mitchell, R. J., Will, R. E., and Teskey, R. O.: Modeling canopy transpiration using time series analysis: 
A case study illustrating the effect of soil moisture deficit on Pinus taeda, Agric. For. Meteorol., 130, 163-175, 2005.

Früh, T. and Kurth, W.: The Hydraulic System of Trees: Theoretical Framework and Numerical Simulation, J. Theor. Biol., 201, 251270, 1999

Gao, Q., Zhao, P., Zeng, X., Cai, X., and Shen, W.: A model of stomatal conductance to quantify the relationship between leaf transpiration, microclimate and soil water stress, Plant Cell Environ., 25, 1373-1381, 2002.

Goldstein, G., Andrade, J. L., Meinzer, F. C., Holbrook, N. M., Cavelier, J., Jackson, P., and Celis, A.: Stem water storage and diurnal patterns of water use in tropical forest canopy trees, Plant Cell Environ., 21, 397-406, 1998.

Holtta, T., Vesala, T., Peramaki, M., and Nikinmaa, E.: Relationships between Embolism, Stem Water Tension, and Diameter Changes, J. Theor. Biol., 215, 23-38, 2002.

Hunt Jr., E. R., Running, S. W., and Federer, C. A.: Extrapolating plant water flow resistances and capacitances to regional scales, Agric. For. Meteorol., 54, 169-195, 1991.

Irvine, J., Perks, M. P., Magnani, F., and Grace, J.: The response of Pinus sylvestris to drought: stomatal control of transpiration and hydraulic conductance, Tree Physiol., 18, 393-402, 1998.

Janssens, I. A., Sampson, D. A., Čermák, J., Meiresonne, L., Riguzzi, F., Overloop, S. and Ceulemans, R.: Above- and belowground phytomass and carbon storage in a Belgian Scots pine stand, Ann. For. Sci., 56, 81-90, 1999.

Jones, H. G.: Plants and Microclimate, A quantitative approach to environmental plant physiology, second edition, University Press, Cambridge, 428 pp., 1992.

Köstner, B., Falge, E. M., Alsheimer, M., Geyer, R., and Tenhunen, J. D.: Estimating tree canopy water use via xylem sap flow in an old Norway spruce forest and a comparison with simulationbased canopy transpiration estimates, Ann. For. Sci., 55, 125139, 1998.

Kowalski, A. S., Overloop, S., and Ceulemans, R.: Eddy fluxes above a Belgian, Campine forest and their relationship with predicting variables, in: Forest Ecosystem Modeling, Upscaling and Remote Sensing, edited by: Ceulemans, R., Veroustraete, F., Gond, V., and Van Rensbergen, J., SPB Academic Publishing, The Hague, 3-17, 2000.

Lhomme, J. P., Rocheteau, A., Ourcival, J. M., and Rambal, S.: Non-steady-state modelling of water transfer in a Mediterranean evergreen canopy, Agric. For. Meteorol., 108, 67-83, 2001.

Loustau, D., Berbigier, P., Roumagnac, P., Arruda-Pacheco, C., David, J. S., Ferreira, M. I., Pereira, J. S., and Travares, R.: Transpiration of a 64-year-old maritime pine stand in Portugal. 1. Seasonal course of water flux through maritime pine, Oecologia, 107, 33-42, 1996.

Martin, T. A., Brown, K. J., Čermák, J., Ceulemans, R., Kučera, J., Meinzer, F. C., Rombold, J. S., Sprugel, D. G., and Hinckley, T. M.: Crown conductance and tree and stand transpiration in a second-growth Abies amabilis forest, Can. J. For. Res., 27, 797808, 1997.

Meinzer, F. C., Hinckley, T. M., and Ceulemans, R.: Apparent responses of stomata to transpiration and humidity in a hybrid poplar canopy, Plant Cell Environ., 20, 1301-1308, 1997.

Meinzer, F. C., Goldstein, G., Franco, A.C., Bustamante, M., Igler, E., Jackson, P., Caldas, L., and Rundel, P. W.: Atmospheric and hydraulic limitations on transpiration in Brazilian cerrado woody species, Funct. Ecol., 13, 273-282, 1999.

Meinzer, F. C., Clearwater, M. J., and Goldstein, G.: Water transport in trees: current perspectives, new insights and some controversies, Environ. Exp. Bot., 45, 239-262, 2001.

Meiresonne, L., Sampson, D. A., Kowalski, A. S., Janssens, I. A., Nadezhdina, N., Čermák, J., Van Slycken, J., and Ceulemans, R.: Water flux estimates from a Belgian Scots pine stand: a comparison of different approaches, J. Hydrol., 270, 230-252, 2003.

Monteith, J. L.: Evaporation and environment, in: The state and movement of water in living organisms, edited by: Fogg., G. F., 19th Symposium for Experimental Science, Cambridge University Press, London, 205-234, 1965.

Monteith, J. L.: A reinterpretation of stomatal responses to humidity, Plant Cell Environ., 18, 357-64, 1995.

Motzer, T., Munz, N., Küppers, M., Schmitt, D., and Anhuff, D.: Stomatal conductance, transpiration and sap flow of tropical montane rain forest trees in southern Ecuadorian Andes, Tree Physiol., 25, 1283-1293, 2005.

Nadezhdina, N., Čermák, J., and Nadezhdin, V.: Heat field deformation method for sap flow measurements, Proceedings Fourth International Workshop on Measuring Sap Flow in Intact Plants. Zidlochoviche, Czech Republic, 3-5 October, IUFRO Publications. Publishing house of Mendel University of Brno, 72-92, 1998.

Nadezhdina, N. and Čermák, J.: The technique and instrumentation for estimation the sap flow rate in plants (in Czech), Patent No. 286438 (PV-1587-98), 2000.

Nadezhdina, N., Čermák, J., and Ceulemans, R.: Radial patterns of sap flow in woody stems of dominant and understory species: scaling errors associated with positioning of sensors, Tree Physiol., 22, 907-918, 2002.

Nadezhdina, N., Tributsch, H., and Čermák, J.: Infra-red images of heat field around a linear heater and sap flow in stems of lime trees under natural and experimental conditions, Ann. For. Sci., 61, 203-214, 2004.

Nadezhdina, N., Čermák, J., Gaspárek, J., Nadezhdin, V., and Prax, A.: Vertical and horizontal water redistribution in Norway spruce (Picea abies) roots in the Moravian Upland, Tree Physiol., 26, 1277-1288, 2006.

Nadezhdina, N., Nadezhdin, V., Ferreira, M. I., and Pitacco, A.: Variability with xylem depth in sap flow in trunks and branches of mature olive trees, Tree Physiol., 27, 105-113, 2007.

Nelder, J. A. and Mead, R.: A simplex method for function minimization, Comput. J., 7, 308-313, 1965.

Neirynck, J., Van Ranst, E., Roskams, P., and Lust, N.: Impact of decreasing throughfall depositions on soil solution chemistry at coniferous monitoring sites in northern Belgium, For. Ecol. Manage., 160, 127-142, 2002.

Op de Beeck, M., Löw, M., Verbeeck, H., and Deckmyn, G.: Suitability of a combined stomatal conductance and photosynthesis model for calculation of leaf level ozone fluxes, Plant Biol., 9, 331-341, 2007.

Oren, R., Phillips, N., Ewers, B. E., Pataki, D. E., and Megonigal, J. P: Sap-flux-scaled transpiration responses to light, vapour pressure deficit, and leaf area reduction in a flooded Taxodium distichum forest, Tree Physiol., 19, 337-347, 1999a.

Oren, R., Sperry, J. S., Katul, G. G., Pataki, D. E., Ewers, B. E., Phillips, N., and Schafer, K. V. R.: Survey and synthesis of intraand interspecific variation in stomatal sensitivity to vapour pres- 
sure deficit, Plant Cell Environ., 22, 1515-1526, $1999 \mathrm{~b}$.

Overloop, S. and Meiresonne., L.: Basiskarakteristieken van het proefvlak Brasschaat, domeinbos de Inslag, Communications of the Institute of Forestry and Game Management, no. 1999/1, 1121, 1999 (in Dutch).

Penman, H. L.: Natural evaporation from open water, bare soil and grass, Proc. R. Soc, A 193, 120-145, 1948.

Perämäki, M., Vesala, T., and Nikinmaa, E.: Modeling the dynamics of pressure propagation and diameter variation in tree sapwood, Tree Physiol., 25, 1091-1099, 2005.

Phillips, N., Ryan, M. G., Bond, B. J., McDowell, N. G., Hinckley, T. M., and Čermák, J.: Reliance on stored water increases with tree size in three species in the Pacific Northwest, Tree Physiol., 23, 237-245, 2003.

Press, W. H., Teukolsky, S. A., Vetterling, W. T., and Flannery, B. P.: Numerical recipes in fortran 90, The art of scientific computing, Second edition, Vol. 2, Cambridge Univerity Press, 921 pp., 1996.

Roskams, P., Sioen, G., and Overloop, S.: Meetnet voor de intensieve monitoring van het bosecosysteem in het Vlaamse Gewest - resultaten 1991-1992, Institute for Forestry and Game Management, Ministry of the Flemmish Community, 191 pp., 1997 (in Dutch).

Sampson, D. A., Janssens, I. A., and Ceulemans, R.: Under-story contributions to stand level GPP using the process model SECRETS, Agric. For. Meteorol., 139, 94-104, 2006.
Scholz, F. G., Bucci, S. J., Goldstein, G., Meinzer, F. C., Franco, A. C., and Miralles-Wilhelm, F.: Biophysical properties and functional significance of stem water storage tissues in Neotropical savanna trees, Plant Cell Environ., 30, 236-248, 2007.

Sinclair, T. R., Holbrook, N. M., and Zwieniecki, M. A.: Daily transpiration rates of woody species on drying soil, Tree Physiol., 25, 1469-1472, 2005.

Steppe, K., De Pauw, D. J. W., Lemeur, R., and Vanrolleghem, P. A.: A mathematical model linking tree sap flow dynamics to daily stem diameter fluctuations and radial stem growth, Tree Physiol., 26, 257-273, 2006.

Stewart, J. B.: Modelling surface conductance of pine forest, Agric. For. Meteorol., 43, 19-35, 1988.

van Genuchten, M. T.: A closed-form equation for predicting the hydraulic conductivity of the soil, Soil Sci. Soc. Am. J., 44, 892898, 1980.

Verbeeck, H., Steppe, K., Nadezhdina, N., Op de Beeck, M., Deckmyn, G., Meiresonne, L., Lemeur, R., Čermák, J., Ceulemans, R., and Janssens, I. A.: Water storage and transpiration in Scots pine: a modeling analysis using ANAFORE, Tree Physiol., 27, 1671-1685, 2007.

Whitehead, D.: Regulation of stomatal conductance and transpiration in forest canopies, Tree Physiol., 18, 633-644, 1998.

Zweifel, R., Item, H., and Häsler, R.: Link between diurnal stem radius changes and tree water relations, Tree Physiol., 21, 869877, 2001.

Zweifel, R., Zimmermann, L., and Newbery, D. M.: Modeling tree water deficit from microclimate: an approach to quantifying drought stress, Tree Physiol., 25, 147-156, 2005. 